\title{
OMUL IISUS, „EXPRESIA” SUPREMĂ A LUI DUMNEZEU, ÎN TEOLOGIA LUI HANS URS VON BALTHASAR
}

Robert Iulian Păun*

Abstract: The concept of figure (Gestalt), that Hans Urs von Balthasar develops with such greatness in his theology, is correlated with the whole vision about the theological aesthetics of the great Swiss theologian. Theological Aesthetics, methodologically speaking, really brought a very important contribution to the theology in general, as it imposes a standard that must always apply, namely: the simultaneous use of the concept with its imposed form. Therefore, insisting in this article on the concept of figure, we wanted to highlight the form reflected in each of us and even more in the person of the young Christian, tired of living in a non-harmonized conceptual world. Jesus Christ is the figure by excellence and we drink of it as we understand it.

Keywords: figure, young, image, expression, harmony, symphony, praise, form, synthesis, Christology, person, universal, concrete, beautiful, truth, ideas, uniqueness, standard, action, mission.

\section{Introducere}

Care este rolul naturii umane, asumată de către Fiul veșnic al lui Dumnezeu ? Am văzut deja răspunsul permanent a lui Balthasar la această întrebare: omul Hristos este expresia lui Dumnezeu1, umanitatea lui Hristos este expresia Tatălui. Mai exact, se poate afirma: omul Iisus, prin experiența Sa umană concretă de Dumnezeu,

\footnotetext{
* PhD Candidate, Faculty of Orthodox Theology, at "1 Decembrie 1918" University, Alba Iulia, Romania.

${ }^{1}$ Paul Gilbert, Corso di metafisisca. La pazienza d'essere, Editura Piemme, Casale Monferrato, 1997, p. 309.
} 
până când a simţit distanțarea și a suferit abandonarea pe cruce, este „expresia unei auto-experiențe inter-trinitare a lui Dumnezeu în distincția persoanelor"2. În categoria expresiei se concentrează reflecția balthasariană despre logica lui Dumnezeu având ca obiectiv modul manifestării divine, adică forma Sa divino-umană de a se dovedi şi de a se face cunoscut ca şi Adevăr absolut, ca un Dumnezeu unic și Treimic.

În lucrarea poliedrică a lui Hans Urs von Balthasar, cuvântul german ausdruck este folosit de sute de ori, împreună cu verbul corespunzător ausdrücken. Ausdruck-ausdrücken înseamnă expresieexprimare, și prin urmare manifestaţie-manifestare, a face evident. Ausdruck este de multe ori sinonim cu cuvântul, cu semnul revelator. Cuvântul german ausdruck corespunde în latină cu expressio (expresie). Autorul nostru, după cum vom vedea, împrumută termenul expresie și rolul său hristologic și trinitar de revelație în Cuvântul întrupat, în special de la Bonaventura. Expressio și impressio (imagine) sunt conceptele fundamentale ale teoriei sale despre frumusețe. Fiul este unica și perfecta imagine a Tatălui, pe care o exprimă cu precizie supremă. Bonaventura subliniază faptul că imagine înseamnă în divin, nu numai exprimarea unei persoane, ci posibilitatea maximă de exprimare, și aceasta din două motive: în primul rând pentru că „,este exprimarea unică a unei identități irepetabile, în al doilea rând pentru că o exprimă în toate sensurile" ${ }^{3}$. Literar expresie (de la ex-premere) înseamnă stoarcere, a scoate prin apăsare, a trimite afară. Figurat termenul înseamnă a reprezenta, a exprima, a manifesta, a arăta, a expune. În limbajul teologic Balthasarian, dependent direct de Bonaventura, expressio-expresie este sinonim cu revelație, manifestare, interpretare și clarificare. Deja Sfântul Ambrozie a vorbit despre expressio personae. Diferite sunt modurile de exprimare, conform numeroaselor forme de activitate a

${ }^{2}$ Hans Urs von Balthasar, Gloria. Una estetica teologica, volumul 1: La percezione della forma, trad. Giuseppe Ruggieri, Editura Jaca Book, SpA, Milano 1994, p. 318.

${ }^{3}$ Hans Urs von Balthasar, Verita di Dio, Teologica, volumul 2, trad. Guido Sommavilla, Editura Jaca Book, SpA Milano, 1990, p. 145. 


\section{$15^{\text {th }}$ International Symposium on Science, Theology and Arts}

spiritului omenesc.

Tot la Bonaventura autorul nostru a întâlnit douăsprezece exemple de exprimare (generationes), care sunt prezente în ființe: patru moduri de efuziune (iluminare prin lumină, încălzire prin foc, fluxul de la sursă, ploaia și roua din nor); patru moduri de expresie (iluminarea fenomenică exprimă obiectul, imaginea modelul, cuvântul vorbitorul, conceptul spiritul rațional); patru moduri de generare (sămânța generează răsadul, rădăcina copacul, pântecele matern fiul, sămânța paternă urmașii). În al doilea grup de exprimare apare conceptul (drept cuvânt interior, dintre care cuvântul este prelungirea) și imaginea. În al treilea grup al exprimării primează forma genezei naturale cea mai perfectă, paternitatea. Prin urmare, în întregime, sunt trei referințe cultural decisive: cuvântul, imaginea și fiul. În domeniul creației, ultimele trei elemente, precum toate celelalte, exprimă „ceva care într-un inaccesibil punct al începutului vieții de apoi trebuie să conțină plinătatea raportului de exprimare"4. Această plenitudine de exprimare constă tocmai în Dumnezeul Treimic, al cărui Lógos este expresia absolută (expressio in summo), este forma expresivă a întregii divinităţi Trinitare ${ }^{5}$. Este explicat fundamentul întregii creaţii în vederea procesului veşnic al Logosului ${ }^{6}$ : „Dumnezeu nu ar fi fost capabil de a crea o creatură în conformitate cu propria Sa voinţă dacă nu ar fi generat Fiul în funcţie de natură ${ }^{, 7}$. Fiecare rezultat este generarea sau consecinţa acestei generări. „În nașterea Cuvântului, totul este spus, în purcederea

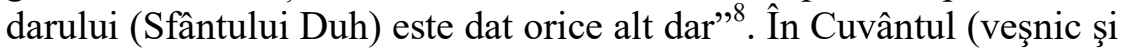
întrupat) coincid atât auto-expresia lui Dumnezeu Tatăl, cât şi

${ }^{4}$ Hans Urs von Balthasar, Stili ecclesiastici, Editura Gia' e non ancora, Milano, 1978, p. 259. Citează pe San Bonaventura, Hexaemeron, XI.

${ }^{5}$ Hans Urs von Balthasar, Verita di Dio, Teologica, volumul 2, Editura Jaca Book, SpA Milano, 1990, p. 275.

${ }^{6}$ Piero Coda, Il Logos e il nulla. Trinità, religioni, mistica, Editura Città Nuova, Roma, 2003, p. 300.

${ }^{7}$ Hans Urs von Balthasar, Verita di Dio, Teologica, volumul 2, Editura Jaca Book, SpA Milano, 1990, p. 269.

${ }^{8}$ Ibidem., p. 269; Ellero Babini, Gli stati di vita di cristiano, Editura Jaca Book, Milano, 1996, p. 195. 
expresia pe care Dumnezeu o poate crea ad extra, în calitate de liber şi gratuit dar de Sine.

\section{Cuvânt, Fiu, Imagine, Expresie}

Trebuie să ne întrebăm: care este numele cel mai potrivit pentru a-L indica pe Fiul lui Dumnezeu în fiinţa şi în manifestare Sa? Pentru Toma D'Aquino atributul central al persoanei a doua este verbum ca şi cuvânt intim (verbum mentis) în care se exprimă Tatăl care este cunoscut. Pentru Bonaventura atributul care rezumă totul este expressio, prin care se rezumă sensul celorlalte denumiri, şi anume Fiu, Imagine şi Cuvânt ${ }^{9}$. Fericitul Augustin zice: ,în acelaşi sens în care El se numeşte Cuvânt se numeşte şi Fiu" ". Generarea Fiului, proprietatea Sa personală, este definită cu diferite nume, care sunt aplicate Fiului ca şi expresie diferită a perfecţiunii Sale. Fiind egal în esenţă cu Tatăl, este numit Fiu, pentru că este la fel de veşnic, este numit reflexie, deoarece este similar în toate, este numit imagine, deoarece este generat în mod spiritual, este numit Cuvânt, „negăsindu-se un singur nume cu care toate acestea se pot exprima simultan"11.

În schimb, după Bonaventura, proprietatea fundamentală a Fiului lui Dumnezeu sau Logosul este aceea de a fi expresie absolută (expressio in summo) a Tatălui pentru că este similar cu El în toate, este a Sa impressio sau amprenta perfectă a naturii Sale. Balthasar optează pentru ideea lui Bonaventura, fără a neglija meritelelui Toma d'Aquino. Însușindu-și categoria centrală a lui Bonaventura, Cuvântul ca şi expresie absolută a lui Dumnezeu, Balthasar vede deschisă calea pentru a putea trata mai de aproape tema revelaţiei divine $^{12}$, şi anume: Cuvântul făcut trup este adevărul lui Dumnezeu. Deoarece Cuvântul este persoană, El nu este nu doar portretul

\footnotetext{
${ }^{9}$ Hans Urs von Balthasar, Verita di Dio, Teologica, volumul 2, op. cit. p. 143.

${ }^{10}$ Fericitul Augustin, La Trinità, Opera omnia. Patrologiae Latinae, Editura Documenta Catholica Omnia, Capitolul 7, p. 87.

${ }^{11}$ Hans Urs von Balthasar, Verita di Dio, Teologica, volumul 2, p. 143.

${ }^{12}$ Vincent Holzer, Le Dieu Trinité dans l'histoire. Le différend théologique Balthasar-Rahner, Editura Cerf, Paris, 1995, p. 31.
} 
exterior al Tatălui, ci dezvăluindu-Se, exprimă atât esenţa Tatălui cât şi personalitatea $\mathrm{Sa}$.

A fi expresie vine de la arhetip. Toate lucrurile sunt adevărate şi sunt capabile să se exprime în virtutea puterii expresive a acelei lumini supreme, şi anume a Cuvântului divin.

\section{Iisus Hristos, imagine și expresie vizibilă a Tatălui invizibil}

În scrierile Noului Testament, Fiul întrupat al lui Dumnezeu este definit expresie (Evrei 1,3), imagine (2 Corinteni 4,4; Coloseni 1,15) şi Cuvânt (Ioan 1,1). Analogia hristologică nu se referă exclusiv la raportul general dintre Dumnezeu şi om, ci se concentrează pe relaţia specifică dintre Cuvântul (Verbum) veşnic şi carnea (caro) muritoare luată de Logos în puterea unirii ipostatice. Aceasta, spune Balthasar, nu este o uniune superioară dintre Dumnezeu şi om, în vederea identităţii; este vorba însă de uniunea definitivă și fără amestec dintre două realităţi cu totul diferite care sunt tocmai natura divină şi natura umană; aceaşi uniune devine „extrema măsură între două incomparabile, Dumnezeu şi omul”"13.

Fiecare existență finită, chiar şi fără viață, are parte de dualitatea de expresie (fenomen) şi ceea ce este exprimat, exprimarea devenind imagine în domeniul senzorial. Totul în Cuvântul făcut trup este exprimarea Tatălui în Sfântul Duh, în sensul că în firea Sa de a fi imagine pământească, este imediat vizibilă firea Sa divină. „Așa cum în Hristos nu există nici un act uman care să nu fie expresia divinului, tot așa nu există nici o manifestare divină care să nu se exprime și să se reveleze altfel decât prin elocvența umanului"”. Înainte de a aprofunda funcţia de om în revelaţia (expresie) lui Iisus, trebuie să precizăm natura de imagine (eikon) prin care Sfântul Pavel 1̂-L defineşte pe Hristos, icoana lui Dumnezeu (2 Corinteni 4,4), imaginea lui Dumnezeu cel invizibil (Coloseni 1,15).

13 Hans Urs von Balthasar, Le Persone del Dramma: L'uomo in Cristo. Teodrammatica, Volumul 3, Editura Jaca Book, Milano, 1978, p. 208.

${ }_{14}$ Tullio Citrini, Gesù Cristo rivelazione di Dio, Editura Scuola Cattolica Hildephonsiana, Varese, p. 187. 
În aceste denumiri, este subliniat alături de exegeţii Gerhard von Rad şi Alfred H. Kleinknecht ${ }^{15}$, faptul că accentul cade asupra identităţii perfecte între eikon şi prototip. În sens grecesc, imaginea, departe de a fi doar o chestiune de conştiinţă departe de realitate, este un participant al realului, este ea însăşi realitatea adevărată ${ }^{16}$. De aceea, Cuvântul desemnează nu doar o reflectare dezvoltată sau, ca să zicem aşa, proiectul unui obiect, ci proiecţia vizibilă a propriei sale intimităţi esenţiale. „Creaturalitatea lui Hristos este expresia eternei sale filiații necreate" ${ }^{\prime 17}$. Apoi, pentru greci imaginea era o iradiere, o manifestare vizibilă a esenţei lucrului şi, ca atare, putea avea ca rezultat o participare substanţială a obiectului. Acestă identitate dintre imaginea lui Hristos şi originalul Tatălui, exprimat de eikon, corespunde cu ceea ce afirmă Sfântul Pavel în imnul hristologic al Epistolei către Filipeni: Hristos, „Dumnezeu fiind în chip”, şi în condiţia de fiinţă ,,întocmai cu Dumnezeu” (Filipeni 2,6). În termenii lui Ioan este exprimat acelaşi lucru: „Cel ce M-a văzut pe Mine L-a văzut pe Tatăl” (Ioan 14,9). De asemenea afirmația Epistolei către Coloseni: „Fiul dragostei Sale” (Coloseni 1,13) înseamnă practic acelaşi lucru: identitatea de esenţă dintre Tatăl şi Fiul, care este aspectul adevărat al Tatălui invizibil, apariţia Sa vizibilă şi nu doar o simplă sau nesemnificantă apariţie (Schein) ${ }^{18}$. Balthasar afirmă că în loc de imagine se poate spune „slava lui Hristos" (2 Corinteni 4,4), „slava lui Dumnezeu pe chipul lui Hristos" (2 Corinteni 4,6). Motivul ultim este că toate promisiunile lui Dumnezeu în sine au devenit „da” şi faptul că Dumnezeu a împăcat lumea cu sine prin Hristos atunci când „L-a tratat ca şi păcat în favoarea noastră" 19 . Așadar prin declaraţia paulină că Hristos este imaginea lui Dumnezeu, ,nu devine nesigură nici personalitatea lui

\footnotetext{
15 Gerhard von Rad şi Alfred H. Kleinknecht folosesc termenul eikón, în articolul GLNT, III, p. 179.

${ }^{16}$ Hans Urs von Balthasar, Verita di Dio, Teologica, volumul 2, trad. Guido Sommavilla, Editura Jaca Book, S.p.A, Milano, 1990, p. 229.

${ }^{17}$ Ibidem, p. 187.

${ }^{18}$ Ibidem, p. 229.

${ }^{19}$ Hans Urs von Balthasar, Gloria. Una estetica teologica. Volumul 7: Nuovo patto, trad. G. Manicardi, Editura Jaca Book, Milano, 2010, p. 264.
} 


\section{$15^{\text {th }}$ International Symposium on Science, Theology and Arts}

Hristos, nici cea a Tatălui care se exprimă în mod personal în Cuvântul întrupat. Aceasta, întrucât este Cuvântul lui Dumnezeu, este atât de personală încât este ea însăşi Persoană. Dar Dumnezeu fiind în mod esenţial acelaşi lucru cu Tatăl şi fiind om, este atât de ascultător-transparent spre Tatăl, încât devine în lume prezenţă vizibilă a acţiunii şi a vorbirii lui Dumnezeu" 20 .

Din toate acestea se poate spune că Iisus Hrisos, cu adevărat imaginea Tatălui, nu este umbra slavei Sale (Evrei 10,1), nu reprezintă o copie tehnică, şi nici o emanaţie fizică, sau o pectogramă statică sau aproximativă a Tatălui, ci, fiind Fiu, este expresia exactă sau amprenta (charakter) substanţei Sale, El este imaginea perfectă şi de aceea El însuşi este iradierea slavei Sale ${ }^{21}$.

În hristologie, deci în misterul trinitar, este tranzitat întregul plan al imaginii. Într-adevăr slava lui Dumnezeu se manifestă ca şi dragoste nemărginită în toată misiunea istorico-mântuitoare a Fiului lui Dumnezeu, care a culminat cu moartea pe cruce şi în darul extrem de sine (Euharistia). „Și tocmai această dragoste absolut incomprehensibilă face comprehensibilă dragostea divină a Tatălui" ${ }^{22}$. Contemplarea sau înţelegerea lui Dumnezeu cel invizibil în Dumnezeu cel vizibil, Iisus Hristos, este implementată în credincios prin Duhul Sfânt: El care este unitatea invizibilului şi a lui Dumnezeu cel vizibil, vărsându-se în inimile credincioşilor, apropie de ei această unitate divină, altfel de neînţeles. În alte cuvinte, este propriu Duhului Sfânt, Duhul Adevărului, de a ne face să înţelegem că „Dumnezeu este dragoste şi adevăr”,23, căci „Cuvântul făcut trup este în lume prezenţa vizibilă de a lucra şi de a vorbi, a lui

\footnotetext{
${ }^{20}$ Ibidem, p. 265.

${ }^{21}$ Emmanuel Tourpe, Différence ontologique et différence onto-théologique : Introduction à la pensée de Gustav Siewerth, în Revue Philosophique de Louvain, numărul 93, 1995, p. 331-369.

${ }^{22}$ Hans Urs von Balthasar, Gloria. Una estetica teologica. Volumul 7: Nuovo patto, p. 265.

${ }^{23}$ Hans Urs von Balthasar, Homo creatus est, Saggi Teologici 5, Editura Morcelliana, Brescia, 1991, p. 289.
} 
Dumnezeu"24.

Dintre cei trei termeni hristologici: expresie, imagine şi cuvânt, în reflecţia lui Balthasar despre teologia revelaţiei, excelează, în mod de necontestat, conceptul de expresie. Dumnezeu nu se foloseşte de natura umană ca de un instrument exterior pentru a exprima din exterior şi de sus tot ceea ce este El, ci ia natura umană, o face a Sa şi se exprimă prin ea, plecând din interiorul Său, prin structura Sa ontologică expresivă. „Sufletul lumii, fiind creat și format de Logosul Divin, oferă Sfântului Duh posibiliatea de a se realiza în toate lucrurile, pentru că tot ceea ce se descoperă în forme ideale în lumina Logosului, se realizează în concret în puterea Duhului Sfânt"25.

Pentru a sublinia interioritatea expresiei lui Dumnezeu în uman, este adoptată această motivaţie: ,caracterul intrinsec al relaţiei de exprimare este că Dumnezeu fiind Creatorul, nu poate abuza de propria Sa lucrare în vederea unui scop străin, în schimb, devenind om, poate doar să o onoreze, să o încoroneze şi să o conducă până la realizarea sa cea mai profundă," 26 .

În termeni filozofici se poate spune că Dumnezeu fiind în acelaşi timp Fiinţă (şi nu o fiinţă lângă altele), în această fiinţă care este omul, „El creează o expresie definitivă, făcând din om limbajul Său, expresia Sa" ${ }^{\prime 2}$. Asta înseamnă că, în Hristos, Dumnezeu poate arăta, în acelaşi timp şi nu în mod alternativ, aşa cum des se afirmă, şi pe El însuşi şi pe om. Şi această revelaţie divină are loc în aşa fel încât relativitatea omului în sine, fiind creatură, nu este constrânsă şi nici oprimată de către absolutul contemporan al divinului.

Subliniind şi explicând rolul interior al „exprimării” hristologice în revelaţia lui Dumnezeu, Balthasar validează în primul rând fundamentul Esteticei sale teologice, în ea este reafirmată mereu

\footnotetext{
${ }^{24}$ Hans Urs von Balthasar, Gloria. Una estetica teologica. Volumul 7: Nuovo patto, trad. G. Manicardi, Editura Jaca Book, Milano, 2010, p. 255.

${ }^{25}$ Vladimir Sergeevič Solov'ëv, Sulla Divinoumanità e altri scritti, Opere scelte 1, trad. Pietro Modesto, Editura Jaca Book, Milano, 1971, p. 163.

${ }^{26}$ Hans Urs von Balthasar, Gloria. Una estetica teologica, volumul 1: La percezione della forma, p. 422.

${ }^{27}$ Ibidem., p. 441.
} 
interdependenţa dintre Figură (Gestalt) şi conţinutul divin (Gehalt) al revelaţiei, şi necesitatea de a percepe din interior evidenţa obiectivă a lui Hristos, icoană şi revelaţie a Tatălui.

„Tot ceea ce este uman în Hristos este revelaţia lui Dumenzeu şi vorbeşte despre $\mathrm{El}$, în viaţa $\mathrm{Sa}$, în lucrarea $\mathrm{Sa}$, în pătimirea $\mathrm{Sa}$ şi în învierea $\mathrm{Sa}$, nefiind nimic care să nu fie expresie, explicare, reprezentare a lui Dumnezeu în limbajul realităţii creaturale. În virtutea unirii ipostatice, în cuvântul întrupat, tot ceea ce este uman se face expresia veşniciei” 28 .

Iisus Hristos este, în opinia lui Balthasar, canonul definitiv al fiecărei abordări ermeneutice a Scripturii: raportul dintre uman şi divin în Scriptură are măsura sa, canonul său în raportul dintre natura umană şi natura divină a lui Hristos. În persoana divină a lui Hristos este locul unde „se va decide raportul dintre Dumnezeu şi om, dintre har şi natură, dintre credinţă şi raţiune"29.

„Hristos, omul plin şi perfect, spune Balthasar deja în primul volum Gloria, face în totalitatea $\mathrm{Sa}$ experienţă de ceea ce este Dumnezeu. Hristos ca şi Dumnezeu întrupat, care î-L arată omului pe Dumnezeu, face însă ca şi Dumnezeu, experienţă de ceea ce este omul" în depărtarea Sa de la Dumnezeu, şi realizează în viaţa Sa de ascultare şi dăruire, modelul de om pe care Dumnezeu 1-a voit cu creaţia $\mathrm{Sa}^{30}$. Acum, devenind om, Fiul lui Dumnezeu face al Său tot ceea ce este specific uman, inclusiv limbajul, modul Său de exprimare. De aceea şi Iisus Hristos vorbeşte limba trupului, limba omului corporal-spiritual. În Hristos, Dumnezeu devine om ca fiecare dintre noi şi se manifestă ca „Unicul irepetibil chiar în fiecare zi”31, limbajul Său fiind cel al unuia care nu va striga şi nu va ridica vocea,

\footnotetext{
${ }^{28}$ Hans Urs von Balthasar, Verbum caro, Sezione quinta. Saggi Teologici 1, Editura Morcelliana-Jaca Book, trad. Giulio Colombi, Milano, 2005, p. 11-27.

${ }^{29}$ Ibidem.., p. 180.

${ }^{30}$ Hans Urs von Balthasar, Gloria. Una estetica teologica, volumul 1: La percezione della forma, trad. Giuseppe Ruggieri, Editura Jaca Book, Milano, 1994, p. 292.

${ }^{31}$ Hans Urs von Balthasar, Verita di Dio, Teologica, volumul 2, trad. Guido Sommavilla, Editura Jaca Book, S.p.A, Milano, 1990, p. 214.
} 
nu va face auzită vocea sa pe drum. Din limbajul lui Dumnezeu în Iisus Hristos fac parte, în esenţă, aşa cum vom vedea, liniştea şi ascunderea. „Misterul și înțelepciunea lui Dumnezeu sunt anunțate în limbajul uman. Cuvântul lui Dumnezeu se exprimă în cuvântul uman. Aici se revelează un mare mister: Cuvântul lui Dumnezeu în cuvântul omului"32.

„În viaţa lui Iisus nu este nimic care, în limbajul psiho-fizic al umanităţii în întregimea sa, nu este exprimare şi prezentare a Tatălui, pentru că fiind întrupat, Fiul este exegeza, interpretarea Tatălui (Ioan 1,18). Omul în Iisus este expresie şi instrument al divinului, şi cu siguranţă nu divinul expresie şi instrument al omului" 33 .

Din unirea Eternului cu timpul, Infinitului $\mathrm{cu}$ finitul, a Cuvântului veşnic al lui Dumnezeu cu cuvântul muritor al omului, rezultă, de asemenea, fluxul universal al revelaţiei lui Iisus. Intradevăr în El, revelaţia lui Dumnezeu devine acel Cuvânt, care este la fel cu existenţa unui om, de aceea este în Omul Iisus Hristos locul unde Dumnezeu întâlneşte orice om, unde vorbeşte fiecărui om şi se adresează tuturor naţiunilor, din orice timp şi orice cultură. În plus, trebuie spus că Dumnezeu, pe care î-L întâlnim în trup, este omul ales de către veşnicie, în care totul este recapitulat în cer şi pe pământ, care răscumpără lumea, ,ridică pe fraţi ca şi copii ai Tatălui",34. Mai mult, Cuvântul lui Dumnezeu în Iisus Hristos se dăruieste la mila fiecărui om, „fără protecţie”,35 în relaţia interpersonală dintre om şi om.

Punctul de plecare al expresiei sau al manifestării vizibile a lui Dumnezeu în Iisus este Dumnezeu însuşi, Dumnezeu cel al

${ }^{32}$ Hans Urs von Balthasar, Mysterium Salutis. Nuovo corso di dogmatica come teologia della storia della salvezza, Volumul 2, ediție îngrijită de Johannes Feiner și Magnus Löhrer, Editura Queriniana, Brescia, 1968, p. 534.

${ }^{33}$ Hans Urs von Balthasar, Verbum caro, Sezione quinta. Saggi Teologici 1, Editura Morcelliana-Jaca Book, trad. Giulio Colombi, Milano, 2005, p. 174.

${ }^{34}$ Hans Urs von Balthasar, La mia opera ed Epilogo, trad. Guido Sommavilla, Editura Jaca Book, Milano, 1987, p. 32.

${ }^{35}$ Hans Urs von Balthasar, Verbum caro, Sezione quinta. Saggi Teologici 1, Editura Morcelliana-Jaca Book, trad. Giulio Colombi, Milano, 2005, p. 34. 


\section{$15^{\text {th }}$ International Symposium on Science, Theology and Arts}

Cuvântului (Ioan 1,1) adevăr veşnic şi credinţă absolută. Am văzut deja că în naşterea veşnică a Fiului lui Dumnezeu se află posibilitatea expresiei absolutului în comuniunea trinitară. Acum, fără nici o nevoie, Dumnezeu a ales modul uman de exprimare pentru a se face cunoscut de către om, pentru a vorbi cu el, pentru a-i dezvălui adevăratul Său chip (Ioan 1,18). Tot în misterul trinitar se sprijină posibilitatea ultimă a manifestării lui Dumnezeu ad extra, în cuvinte umane: pentru că Dumnezeu are în El însuși Cuvântul veşnic, care îL exprimă continuu, este exprimabil în sens absolut și, având în vedere că acest Cuvânt a luat formă de om şi exprimă prin acţiuni şi prin cuvinte umane ceea ce el este în Dumnezeu, este înțeles de către om. Prima realitate fără a doua, observă autorul în acest context, nu ne-ar aduce nici un beneficiu iar a doua fără prima nu ar putea fi gândită.

Omul, singur, este inadecvat pentru a exprima divinul. „Atât sub raport existențial, cât și artistic și teologic, cuvântul totdeauna limitează. Cuvântul uman se mișcă, acționează și este eficient în spații comune, el nu are acces de fapt în abisurile cunoașterii și în infinitul existenței. Acele realități şi dimensiuni sunt mai presus de cuvântul uman, pentru că se dovedesc inexprimabile prin el, indicibile" $"$. Este încă valabilă vechea zicală: între finit și infinit nu există nici o proporție (finiti ad infinitum nulla est proportio). Numai atunci când Cuvântul veșnic, în mod liber și suveran, adoptă natura umană, aceasta poate deveni în întregime expresie a Persoanei divine a lui Hristos, care, la rândul Său, î-L exprimă pe Tatăl.

Balthasar spune că Fiul lui Dumnezeu făcut om este vizibilitatea invizibilului și, prin urmare, ,summum-ul revelaţiei”37. Iisus nu este o reproducere mecanică a Tatălui, ci ca şi Fiu ales și iubit de Tatăl, este aceeași dragoste nemărginită a Tatălui care apare în istorie și se oferă în ascultare necondiţionată. Şi din moment ce această ascultare, cu care Fiul se identifică în mod personal până la a

\footnotetext{
${ }^{36}$ George Remete, Cunoaşterea prin tăcere, Alba Iulia, Editura Reîntregirea, 2011, p. 9.

${ }^{37}$ Hans Urs von Balthasar, Gloria. Una estetica teologica, volumul 1: La percezione della forma, p. 291.
} 
face scopul misiunii Sale, este prin esenţă dragoste, atunci trebuie să repetăm că tocmai în kenoza lui Hristos (și numai în ea) apare misterul intim și intrinsec al iubirii lui Dumnezeu care, în sine, este Treimic.

Balthasar sublinează faptul că Noul Testament, în ciuda aparențelor, este mult mai profund istoric față de Vechiul Testament. În abisul istoricității umane, coboară, se scufundă Cuvântul veșnic al lui Dumnezeu, pentru a aduce lumii plinătatea lui Dumnezeu în trup, pentru a se asigura că ființa umană este o expresie a veșniciei. Din acest motiv, devenind om, cuvântul lui Dumnezeu a vrut să umble în timp, și în toată călătoria Sa, limbajul omului a fost pentru Dumnezeu, aşa cum am mai spus, în primul rând, expresia directă a adevărului Său. Dar, manifestând misterul Său cel mai intim ca şi Absolut, Dumnezeu a arătat în Iisus Hristos ceea ce este omul înaintea lui Dumnezeu şi în Dumnezeu, ca orice om, şi Cuvântul făcut trup a trecut prin acele etape de dezvoltare, de limbă, care caracterizează orice existență umană realizată: etapa de prunc, tânăr, om matur, pentru a intra, în întregimea $\mathrm{Sa}$, în faza specifică a patimei şi a Învierii.

Dumnezeu vorbește ca un om în toate evenimentele care constituie existența istorică a lui lisus: naștere, persecuție, ascundere, rugăciune, sărăcie, ispită, decizie, predare și ucenicie, prietenie și dușmănie, luptă, evadare, bucurie și durere, tortură, moarte, îngropare. În toate aceste evenimente există întotdeauna acea perfectă corelație, despre care am precizat şi în care toată fiinţa umană devine expresia veșniciei, ca şi proiecție a unirii ipostatice dintre Dumnezeu şi om. Astfel, se poate spune că Cuvântul Său pronunțat este existență exprimată și existența Sa este, în totalitate, Cuvânt al lui Dumnezeu, al revelație lui Dumnezeu. Trebuie să mai subliniem faptul că tot ceea ce Dumnezeu a avut de spus sau de dat lumii a găsit loc în acest om, Iisus din Nazaret, în întregimea Sa ca om care vorbește și tace, lucrează și suferă, se roagă sau pur și simplu există, totul în El devine cuvânt, expresie, limbaj și astfel revelația misterului trinitar al lui Dumnezeu. 


\section{$15^{\text {th }}$ International Symposium on Science, Theology and Arts}

\section{Cuvântul ca și „acțiune” a lui Dumnezeu}

Înainte de a încheia această secțiune centrală și fundamentală a viziunii lui Balthasar, mai trebuie specificat că, dacă Cuvântul lui Dumnezeu a devenit carne pentru ca noi să $\hat{i}-\mathrm{L}$ putem înţelege în limba noastră umană, acest lucru nu trebui să ne facă să uităm că Cuvântul lui Dumnezeu este întotdeauna și în acțiunea Sa, pentru că „în Iisus există indivizibilitatea dintre exprimare și acțiune" ${ }^{, 38}$. „Există sau nu un «limbaj» al făpturii, în sensul strict obiectiv? Sau ceea ce numim noi „sensuri, mesaje, și limbaje” ale făpturii către om nu sunt altceva decât simple reflectări, ecouri sau reverberații ale sufletului uman asupra existențelor ne-spirituale care se întorc pur și simplu la expeditor, iar acesta le precepe ca și cum ar aparține obiectiv acelor existențe ca expeditoare efective și prin aceasta le acordă o «obiectivitate» pe care de fapt nu o au?

Este «limbajul» făpturii un act pur subiectiv și de fapt o iluzie?”39. Spre deosebire de cuvântul uman, „Cuvântul întrupat este acțiune în sens intra-divin, în măsura în care Cuvântul este acțiunea generatoare a Tatălui, și apoi pentru că prin intermediul Duhului Sfânt L-a făcut om pe Fiul Divin, și pentru că Cel întrupat este Cuvântul Tatălui, deoarece face mereu voia Tatălui. În acest sens El este împlinirea unitară a Pactului care până acum a avut două laturi, este împlinirea promisiunii Pactului cerută de Dumnezeu oamenilor şi este împlinirea răspunsului Pactului de la om la Dumnezeu"40. Conform expresiei curente a lui Balthasar, Iisus Hristos este Pactul devenit persoană. Aşa a fost El în virtutea ascultării Sale filiale.

Contextul lingvistic şi teologic pentru a înţelege că cuvântul lui Iisus nu este doar o simplă afirmație orală, dar că, Cuvântul Său este deja acțiune în sine, acțiune puternică, este dată de semnificatul vetero-testamentar a lui dābār. Acesta, în afară de cuvânt, mai înseamnă şi lucru, eveniment. După cum putem vedea chiar şi în primul capitol biblic al creației, Cuvântul lui Dumnezeu creează ceea

\footnotetext{
${ }^{38}$ Hans Urs von Balthasar, Verita di Dio, Teologica, volumul 2, op. cit., p. 4.

${ }^{39}$ George Remete, Cunoașterea prin tăcere, op. cit., p. 117.

${ }^{40}$ Hans Urs von Balthasar, Homo creatus est, Saggi Teologici 5, op. cit., p. 290.
} 
ce spune. Aceasta este expresia atotputerniciei și a măreției lui Dumnezeu, pentru care a spune şi a pune în existență sunt una şi aceeași: cu o mare putere Dumnezeu aruncă un cuvânt împotriva lui Iacob, și aceasta cade asupra lui Israel (Isaia 9,7). Şi când profeții devin vestitorii Cuvântului lui Dumnezeu, atunci Dumnezeu poate prin intermediul lor să „facă bucăți pe Israel” (Osea 6,5 $)^{41}$. Eu-L divin, se dovedește în sine ca un agent vorbitor, care vorbindacționând dezvăluie câte ceva din esența $\mathrm{Sa}$, din fiinţa $\mathrm{Sa}$ unică și incomparabilă, diferită de tot ceea ce este lumesc. Prin Cuvânt, Eu-1 Infinit cheamă finitul în propriul Eu, îi vorbește gură către gură, îl pătrunde în inimă și, recreîndu-l, î-1 convoacă către răspunsul responsabil, de dragoste. $\mathrm{Cu}$ alte cuvinte, având în vedere teologia biblică rezultă că pentru Dumnezeu $a$ spune bine este una cu creația Sa. „Pornind de la fapta lui Dumnezeu, credinciosul nu poate acționa altfel decât înspre ea, fapta sa e, în esență, eshatologică, sau (întrucât cuvântul e prea încărcat cu semnificații), parusială. El acționează în vederea reapariției necesare din punct de vedere creștin a lui Hristos în slava Iubirii devenite revelate, atotjudecătoare și atotrestauratoare la capătul (atemporal) lanţului tuturor faptelor temporale. Acțiunea merge spre viitorul absolut, deasupra istoriei relative a lumii (Paul Schütz)" ${ }^{\text {,2 }}$.

Putem spune cu uşurinţă că prin termenul Cuvânt, Eu-1 divin al lui Iisus nu intenţionează un simplu discurs, ci o exprimare totală a lui Dumnezeu. În Hristos, afirmă Balthasar care dă importanţă Cuvântului, forţei Sale creatoare, mântuitoare, cuvântul, puterea de a lucra şi suferinţa răbdătoare, sunt acelaşi lucru. În condescendenţa Sa faţă de slăbiciunea umană, Iisus le cere celor care nu vor să creadă în cuvintele Sale să creadă, măcar, în lucrările Lui, acestea mărturisesc că El este trimisul Tatălui (Ioan 14,12).

Într-adevăr, Iisus se referă la coincidența dintre cuvintele Sale și faptele Tatălui: Cuvintele pe care vi le spun nu le vorbesc de la Mine, ci Tatăl - Care rămâne întru Mine - face lucrările Lui (Ioan

\footnotetext{
${ }^{41}$ Hans Urs von Balthasar, Verita di Dio, Teologica, volumul 2, op. cit., p. 240. ${ }^{42}$ Hans Urs von Balthasar, Iubirea formă a revelației, Colecția Communio 25, trad. Ioan Inescu, Târgu-Lăpuş, Editura Galaxia Gutenberg, 2005, p. 94.
} 


\section{$15^{\text {th }}$ International Symposium on Science, Theology and Arts}

14,10); Deci cele ce vorbesc $\mathrm{Eu}$, precum Mi-a spus Mie Tatăl, aşa vorbesc. (Ioan 12,50). Lucrările despre care Iisus vorbește și pe care El le realizează imitându-L pe Tatăl Său, nu sunt doar minunile făcute de către $\mathrm{El}$ cu degetul lui Dumnezeu, ci, deasemenea, și toate semnele vieții Sale, ascunse și publice, culminate în semnul lui Iona, adică în moartea și învierea Sa. Este, în acest ultim semn unde Dumnezeu S-a exprimat cel mai mult, în Fiul făcut carne: ne-a iubit până la extrema dăruire de sine. „Cu moartea lui Iisus este împlinită judecata lumii, iar cu învierea lui Iisus este împlinită învierea lumii”“43. Astfel, ultimul Cuvânt al lui Dumnezeu în lume și despre lume este în mod clar recunoscut ca iubire trinitară. Acela al pătimirii şi al morţii pe cruce este de asemenea limbajul lui Dumnezeu, care este ușor de înțeles de către toți, pentru că este expresia lui Dumnezeu care vine, nu din constrângere, ci din dragoste, nu provine din fatalitate (așa cum se pare că afirmă Heidegger), ci din ascultarea extremă a Fiului lui Dumnezeu.

\section{Concluzii}

Ideea centrală despre ceea ce am spus până acum, despre expresia hristologică, poate fi rezumată în următoarele afirmaţii: „Dumnezeu se exprimă și se explică pe Sine Însuși în existenţa umană și în experiența acestui om care este Iisus din Nazaret. Dumnezeu a stabilit o relaţie cu toţi oamenii, a intrat în raport intim cu ei, în simţul, atingerea, în cuvântul, în viaţa şi în suferinţa omului; şi pe de altă parte, omul are o relaţie cu Dumnezeu în legătură cu auzul, atingerea, vorbitul, cu viaţa şi cu suferinţa lui Iisus" ${ }^{\text {"44 }}$. Dar omul Iisus, ca limbaj sau expresie directă şi adecvată a Tatălui, nu doar că preferă cu corpul şi cu sufletul, Cuvântul lui Dumnezeu, cum au făcut profeţii, ci dimpotrivă, El este Cuvântul lui Dumnezeu în

\footnotetext{
${ }^{43}$ Hans Urs von Balthasar, Anzitutto il regno di Dio. Due saggi sulla parusia biblica, trad. Velasio de Paolis, Editura Queriniana, Brescia, 1968, p. 15.

${ }^{44}$ Hans Urs von Balthasar, Gloria. Una estetica teologica, volumul 1: La percezione della forma, op. cit., p. 457.

${ }^{45}$ Hans Urs von Balthasar, Anzitutto il regno di Dio. Due saggi sulla parusia biblica, trad. Velasio de Paolis, Editura Queriniana, Brescia, 1968, p. 11.
} 
Sine, pentru că este prin natura Sa originală, Cuvântul Tatălui. Devenind om şi trăind, vorbind, lucrând ca şi om, în condiţia umană însăşi, El a adus lumii declaraţia decisivă a lui Dumnezeu, care rezumă şi încheie revelaţia Cuvântului. Toate acestea înseamnă, în cele din urmă, că omul Iisus nu este un simplu transmiţător al Cuvântului, ca şi cum acesta ar fi trecut pe lângă El, atingându-L. În schimb, Cuvântul, despre care Iisus spune şi atinge până și sacrificiul suprem de sine, curge de la El ca de la sursă şi se răspândeşte în mod perceptibil, sonor şi, prin urmare, credibil prin intermediul naturii umane, făcut propriu de Cuvântul întrupat. Exprimat fiind prin sunete umane sensibile şi corporale, cuvântul lui Iisus rămâne propoziţia ultimă şi definitivă a unui discurs, pe care Dumnezeu 1-a început cu crearea universului şi a omului şi care, până la ultimul cuvânt, nu va fi nici întrerupt, nici redirecţionat. Astfel, putem să înţelegem Cuvântul ca și putere și acțiune răscumpărătoare a lumii. „Dacă eternul Cuvânt al lui Dumnezeu, care poate să spună despre Sine: Cerul și pământul vor trece dar cuvintele Mele nu vor trece (Matei 13,31), a devenit cu adevărat om, atunci, chiar dacă pare paradoxal, în conștiința acestui om apropierea de moartea Sa coincide cu finalitatea cerului și a pământului’"45.

${ }^{45}$ Hans Urs von Balthasar, Anzitutto il regno di Dio. Due saggi sulla parusia biblica, trad. Velasio de Paolis, Editura Queriniana, Brescia, 1968, p. 11. 